\title{
ULTIMUS ROMANORUM
}

THE passing of Professor Priestley Smith in his 88th year is truly the breaking of a link with the past. For more than 50 years his voice has been a dominant factor in all that concerns British Ophthalmology; and we, of the Brit. Jl. of Ophthal., in particular owe him a deep debt of gratitude.

Mr. Priestley Smith began life as an engineer, and it was a happy day for medicine when he decided to take up eye work. After having been house surgeon to the Birmingham Eye Hospital for two years, he became, in 1874, a clinical assistant to Sir William Bowman at Moorfields, and then returned to Birmingham.

His work, on glaucoma in the late seventies of last century has stood the test of time and is recognised the world over as one of the few positive facts in a realm of speculation as to the causation of this disease.

An original member of the Ophthalmological Society of the United Kingdom, he was at the time of his death the senior pastpresident. Innumerable honours have been awarded to him, culminating last year in the Gullstrand Gold Medal of the Swedish Medical Society; but what he probably valued most of all was the affectionate regard in which he was held, not only in Birmingham but throughout the British Empire, wherever ophthalmology is taught. And now that his race has been run, we may, in this tribute, echo the words of Marc Antony of Brutus.

"This was the noblest Roman of them all."

\section{CONCILIUM OPHTHALMOLOGICUM}

THE Fourteenth International Congress of Ophthalmology opened in Madrid on Sunday, April 16. A meeting of the International Council had taken place the evening before, and at 10 a.m. in the amphitheatre of the University the Inaugural Session opened under the patronage of His Excellency Don Niceto Alcalá Zamora, President of the Spanish Republic, in the presence of the Ministers of Public Instruction and of Marine, the Director of Hygiene, the Rector of the University, the Dean of the Faculty of Medicine and over six hundred members of the Congress.

Professor Van der Hoeve, as President of the International Council, opened the proceedings with his usual enviable polyglot eloquence. He spoke in turn in French, English, German, Italian and Spanish with that grace and charm of manner which thase of 
us who were present at Amsterdam remember so well. He greeted the Spanish authorities in the name of the Congress, but before proceeding to the business of the meeting he spoke with emotion of the losses sustained by ophthalmology since the last Congress in the deaths of Professor Lundsgaard, Professor Fuchs, Professor Roselli, Professor Axenfeld and Mr. Treacher Collins. The Congress rose and stood in silence to their memory. "But," continued Professor Van der Hoeve, "life goes on and we must look ahead. The thanks of the Congress are due to the Authorities of the Spanish Republic for their invitation and they are to be congratulated as much on the great future which is before their magnificent country as on its glorious and historic past."

The President of the Congress, Professor Márquez, then rose. He thanked President Zamora for his patronage of the Congress and then proceeded to welcome the various nations taking part. "I will begin," he said, "with two nations, reckoned small by the extent of their territory but great in the position they occupy in the history of ophthalmology-Holland and Belgium. In Belgium was founded in 1838 the first Journal of our specialty, Annales d'Oculistique, while the First International Congress was held there in 1857. Holland needs no further plea for fame than that it is the country of Donders and Snellen."”

He then passed on to speak of the great ophthalmologists of the other countries represented, and ended with a hope for the fruition, practical and theoretical, of the work of the present Congress.

An interesting and inspiring moment followed when the message of the great Spanish doyen of Science, Ramón y Cajal was read to the Congress. He wrote "May I be permitted, from this retreat of my declining years, to send my cordial and enthusiastic greetings to those illustrious foreign scientists who have come to honour the humble science of Spain by bringing forward the fruit of their ophthalmological experience and theoretical investigations. I regret that my infirmities prevent me to-day from participating with my learned colleagues in the fertile work of the Congress. I hope that perhaps, if I am well enough, I may be able to send, if not for one of the meetings, at any rate for publication in the Proceedings a short histologico-physiological analysis of those points still doubtful in the structure of the retina. Sirs, I cannot end my greeting without a cordial hand shake to all of you, and in particular to the foreign members. May they take back with them at the conclusion of the Congress an impression of well-wishing and respect for the Renaissance of Spanish Science."

This message from the greatest authority on the structure of the retina was received with acclamation and will remain the more firmly in our memories since we have as mementos the beautiful plaques of the head of the savant presented to us by Professor Márquez. 
The President of the Spanish Republic then rose and in a most eloquent and impressive speech welcomed the members of the Congress to Spain. He spoke of the happy coincidence of the Congress with the celebration of the Second Anniversary of the Spanish Republic. The work of the Congress for the benefit of humanity was a fitting accompaniment to the efforts of a country attempting to fulfil its destiny in the history of modern civilisation. "Some of you," he said, "have come here attracted by a legend, since for the men of the North, Spain is ever the land of sunshine. Others may have been discouraged by another legend the falsehood of which we want you to judge. Nations are like blind men. You have come to visit a nation which has had its period of blindness, but now the scales have fallen from our eyes and to-day we feel only the lively consciousness of the solidarity of the human race. In the name of a people striving only for the common good of humanity I salute you."

The Foreign Representatives then spoke briefly in turn, thanking the Spanish National Committee for its invitation and expressing their pleasure in it. The representatives of the various countries were as follows :-

\begin{tabular}{|c|c|c|}
\hline France & & Professor Terrien. \\
\hline Great Britain & $\ldots$ & Sir John Parsons. \\
\hline United States & $\ldots$ & Dr. Walter Parker. \\
\hline Italy ... $\quad .$. & $\ldots$ & Professor G. Ovio. \\
\hline Germany & $\ldots$ & Professor Emil Krückmann. \\
\hline Belgium & $\ldots$ & Professor van Duyse. \\
\hline Spanish America & $\ldots$ & Professor Demaría. \\
\hline Scandinavia ... & $\ldots$ & Professor Nordensen. \\
\hline Japan & $\ldots$ & Professor Oguchi. \\
\hline Portugal & $\ldots$ & Professor Sousa. \\
\hline Poland & $\ldots$ & Professor Szymanski. \\
\hline Other countries & $\ldots$ & Professor Emil de Grosz. \\
\hline
\end{tabular}

Don Fernando de los Ríos, Minister of Public Instruction, then opened the Congress in the following words "Welcome to Spain! In the name of the Spanish Government I declare this Congress open. My most ardent desire is that success will attend and reward your labours."

The members then returned to the Palace Hotel where the Scientific and Industrial Museums were opsned.

The afternoon was occupied by a series of demonstrations in the Lecture Theatre of the Congress in the Hotel. Many of these were of great interest and although it is not possible to describe them all, certain of them must be mentioned as of outstanding merit both ophthalmologically and technically. In the first place the three films of the afternoon were of great interest. Dr. López 
Lacarrère (Madrid) showed his new method of cataract extraction by electro-coagulation of the lens (Electro-diaphakia). Part of the film was an explanation of the stages of the operation by animated drawings and was a revelation of the possibilities of instruction and demonstration by this method. The operation itself was then seen, together with many experiments on the rigidity and adhesiveness of the lens after electric coagulation.

A second film shown by Dr. Castroviego (New York) dealt with experimental transplantation of the cornea in rabbits. Points of interest in the technique were that scarring of the cornea is first produced with $\mathrm{CaO}$, that the graft is cut with a double-bladed knife, finished with scissors and is quadrilateral, and finally that no sutures are inserted in the cornea, the graft being kept in place by a large conjunctival flap. The results appeared to be good.

The third film (Dr. Lijó Pavía, Buenos Ayres) was indeed a triumph of technical patience and skill. It was a direct cinematograph picture of the pulsations of the retinal vessels seen during the use of Bailliart's tonometer and the ingenuity and inventiveness required to produce it must have been remarkable. Pulse records and blood pressure estimations on the same patients, were also seen and the uses of the method in the diagnosis of raised intracranial tension explained.

Other items during the afternoon included a series of colour photographs of the fundus (Sabbadini-Rome) with detachments, before and after operation, and an even more interesting series showing a green colouration of certain fundus lesions which becomes accentuated by means of colour photography (Lijó Pavía).

In the evening a Gala Ball took place in the Palace Hotel, accompanied by an exhibition of Spanish dancing by Señorita Morales, and affording opportunity for the friendly and social intercourse which is so valuable an aspect of an International Congress.

The second day (April 17) was dedicated to the reading of communications of scientific importance and to the Meeting of the International Association for the Prevention of Blindness. A Congress which includes in its programme nearly 200 original papers cannot obviously be reported in full, but at the risk of seeming invidious one must attempt to mention at least a few of the outstanding items of interest. Of Monday's papers probably the most interesting were Dr. Troncoso's (New York) paper on gonioscopy and Dr. Comberg's (Berlin) demonstration of the validity of Helmholtz's theory of accommodation. Dr. Arjoria (Madrid) described a new operation for chronic dacryocystitis. Drs. Cohen, New and Killian discussed experiments on the vitreous gel.

On the morning of April 18, the first of the two main subjects for discussion (Tuberculosis of the Iris and Corpus ciliare) was opened by Dr. E. V. L. Brown (Chicago) who read a paper on modern 
methods of treatment, urging the importance of the fact, still too frequently overlooked, that the general treatment of the patient is of equal importance with the purely ophthalmological.

The second opener was Professor Igersheimer (Frankfort) who gave a brilliant exposition of the pathological anatomy of the disease. His classification of the various types, and the illustration of these by means of microscopic preparations of great beauty was a most interesting item. He was followed by Dr. H. Lagrange (Paris) who spoke most ably on "Diagnosis and Differential Diagnosis." A lively discussion followed, in which many members took part. The afternoon was devoted to original papers bearing on the subject of tuberculosis and later to papers on other subjects.

At 7 p.m. was held a reception at the National Palace. Here the members from the various countries were presented in turn to President $Z$ amora, and then passed into a large and imposing hall where light refreshments were offered. For the first few days some slight surprise was felt by the more Northern members with regard to the hours kept in Madrid, as was perhaps only natural in a land where afternoon tea is served at 7 p.m., and dinner at 10 p.m. After dinner, a Gala Concert of the Orquestra Sinfónica of Madrid was held in the Teatro Español; this included selections from Beethoven, Dubussy, Wagner, and also a representative selection from purely Spanish composers, including Granodas, AlbénizArbós and Giménez.

The following day (April 19) opened with a short session for discussion of the possibility of the internationalisation of visual standards. Various propositions were put forward with regard to the regulations governing the visual acuity required in aviation, in railway employees, sailors and drivers of motor vehicles. This was followed by an administrative session, after which an excursion was organised to the Escorial for lunch. This remarkable pile, part monastery, part mausoleum, is one of the most famous buildings of Spain. It stands on the South Eastern slopes of the foothills of the Sierra di Guadarama, about 25 miles from Madrid, and the visit to it proved of extraordinary interest from many points of view. The evening was graced by a reception at the Town Hall of Madrid.

The fifth day of the Congress was dedicated to the second great subject for discussion, namely, "Detachment of the Retina." Professor Arruga (Barcelona) opened with an admirable paper on aetiology, which was followed by two opening papers on treatment, medical and operative, by Professor Ovio and Professor Vogt respectively. A lively discussion followed, in which at least two dozen members took part. Further original papers on detachment were read, and the meeting adjourned for the day. The afternoon, unfortunately, showery and rather cold, was given up to a bull fight, attended by a large number of foreign members anxious to see this 
historic national sport of Spain. The members of the Spanish National Committee did a great deal to add to the interest of the spectacle by explaining the various evolutions of the toreros and the meaning of the ritual. It was interesting to hear that the second bull was dedicated to a member of the Congress, Dr. Lijó Pavía.

At 10 p.m. the official Banquet was held in the Palace Hotel. The Minister for Public Instruction presided and the whole proceedings afforded a fresh manifestation, if any were needed, of the international spirit of science. Professor van de Hoeve opened the speeches. He spoke in the name of Holland and said that although the Congress was not yet ended it was obvious that it was extremely successful. All those who had had the organisation of such things knew the tremendous amount of work entailed. He added his thanks also to the Spanish authorities and said that all those returning to their own lands would thereafter give the lie to the saying of Pio Baroja that "Madrid es una ciudad de buenas entradas y de mejores salidas." The President had said that there were certain legends concerning Spain. One that would certainly be dissipated was that Spanish invitations were purely formal. In this case, however, the reality had surpassed all the promises.

Dr. Bailliart next spoke in the name of the ophthalmologists of France. He thanked Professor and Madame Márquez and praised the rich feast of work and of lighter amusements offered us so freely by our Spanish colleagues. He recalled the intimate relations of France and Spain, both racial and historic, and ended "Aprés avoir mélé le sang de nos rois, mêlons aujourd 'hui le clair rayon de nos libertés. Je lève mon verre pour l'Espagne d'hier et demain, chevaleresque jusque dans ses revolutions," a piece of eloquence loudly applauded.

$\mathrm{Mr}$. Paton here rose in the name of Great Britain and speaking in Spanish expressed the great pleasure he felt in being able thus to thank his colleagues who had elected him member of the Société Hispano-Americaine d'ophthalmologie. Every Englishman, he said, had his castle in Spain, and to-day one of his own dreams was realised. He had visited the land of El Greco and Velasquez, had seen the beautiful city of Madrid famous throughout the world for its incomparable treasures of art and had even at Altamira, been able to admire the work of that palaeolithic artist who can be looked on as the forerunner of so many centuries of creative power in Spain.

Professor Bardelli next rose in the name of Italy to thank the National Council. He recalled the last Congress at Amsterdam and spoke of the many instances of the progress of our science since then.

Professor Krückmann wishing to avoid omissions preferred to speak in general terms. He had noticed that no country reached grandeur without discipline and the same applied to science and to 
scientific societies. Our success was a guarantee of mutual understanding and general peace. The meetings of the present week went to show the changed spirit. Fatalism had disappeared, each new problem was only a motive for renewed effort in the pursuit of new solutions.

Dr. van Duyse brought the thanks of Belgian ophthalmologists for their cordial reception. He described the extreme modesty of Professor Márquez and Dr. Poyales and spoke of the gesture of hospitality of the latter in travelling to Irun to welcome the foreign members at their entry into Spain.

Professor Szymanski then spoke for Poland and Dr. Manes for the Argentine. The latter spoke with enthusiasm of those who had set an example of travelling long distances to the Congress.

Professor Nordensen spoke of the friendship of Gustav Retzius and Ramón y Cajal and of the awarding of the Nobel Prize by the Faculty of Medicine of Stockholm to the latter.

Professor Sobhy Bey brought the greetings of the Egyptian University and spoke of the long medical tradition of Egypt. The discovery of the use of copper sulphate and the original experiments on the circulation of the blood had both been made in Egypt.

Dr. Parker spoke for the United States. He said that the Americans have an old debt of gratitude towards Spain-for did not Spain send Christopher Columbus to discover their continent?

Dr. Fialho then spoke for Brazil and Dr. Arruga for Spain, and after Professor de Grosz had proposed the health of the ladies present, Professor Márquez rose. He, with characteristic modesty, gave the credit of the success of the Congress to his secretaries, Drs. Poyales and Lacarrère. He spoke of the need for unity in scientific matters at this time of world crisis and saluted the guests as colleagues in a good cause which knew no boundaries of nationality.

The Minister of Public Instruction, Don Fernando de los Ríos, then terminated the proceedings by an eloquent speech in French. He said that not only were such gatherings of the utmost importance as affording opportunities for discussion of scientific problems but also from the point of view of promoting intercourse between nations and as affording chances for the discussion of many problems other than scientific. He drank to the progress of science and to the unity of humanity.

The following day (April 21) was devoted to further papers on Detachment of the Retina, among which may be mentioned $\mathrm{Mr}$. Shapland's interesting analysis of the Moorfields' results. The discussion of the International League of the Fight Against Trachoma also took place on this day. Many of the members were also present at a most enjoyable cocktail party given by Drs. Poyales and Criado at the hospital of San José and Santa Adela. 
The Congress was finally brought to a close on Saturday, when it adjourned to Toledo for lunch. This reunion will stand out for many of us as one of the most enjoyable times of the whole week. The setting of the farewell lunch in the beautiful and historic city of Toledo was in itself a happy idea, but it was sheer inspiration to have set the tables in the cloisters of the old Monastery of San Juan de los Reyes, and to have given us the Spanish costumes of our dreams on those who waited on us. The whole décor was indeed the most picturesque and charming imaginable, and the Congress broke up with a feeling not only of intense pleasure and satisfaction, but also of sincere gratitude to our Spanish colleagues for the immense amount of work they had done to make the Congress so great a success.

IDA C. MANN.

\section{ABSTRACTS \\ I.-GENERAL MEDICINE}

(I) Ramsay, A. Maitland (St Andrew's).-An analogy between eyestrain and cardiac pain. Lancet, November 14, 1931.

(1) Ramsay's article, dealing with heart muscle and ciliary muscle, occupies some ten columns of the Lancet, and, although the author has, we think, written on the same subject before, he always presents it in an interesting light and often in a novel manner. Many of the facts are already familiar to ophthalmologists on the one hand and physicians on the other. Prognosis, however, is more a matter of wisdom than of knowledge of facts and it is to the subject of prognosis as discussed by Ramsay that the reviewer would draw attention. Dealing with the evil results of a morbid psychology on the symptoms of eyestrain the author Says :- "The patient is so obsessed by her visual discomforts that she wears dark glasses constantly, and makes no effort to use her eyes, notwithstanding the fact that they are structurally sound and that any error of refraction has been corrected. No matter how often it has been contradicted, she constantly reminds herself of the unfavourable prognosis she got from a doctor many years previously, and no one can persuade her to modify the restrictions imposed upon the use of her sight at that time." The following wise dictum of the late Sir James Mackenzie, here quoted, is well worth bearing in mind :- "The injudicious prognosis of a doctor may have calamitous results, .... he should not only consider his words, but also his method of expression" and "should weigh carefully the effect of his prognosis upon his patient." (These 